\title{
Determination of Safe Apnoea Period in Relation to Haemoglobin Concentration at Komfo Anokye Teaching Hospital
}

\author{
Tweneboah George ${ }^{1}$, Jane Acquaye ${ }^{2}$, Tsiri Agbenyega ${ }^{3}$, Lorraine Sallah ${ }^{3}$ \\ ${ }^{1}$ Department of Anesthesia, Komfo Anokye Teaching Hospital, Kumasi, Ghana \\ ${ }^{2}$ Clinical Research Assistant, Komfo Anokye Teaching Hospital, Kumasi, Ghana \\ ${ }^{3}$ Department of Physiology, Kwame Nkrumah University of Science and Technology, Kumasi, Ghana \\ Email: maame.jenny@yahoo.com
}

How to cite this paper: George, T., Acquaye, J., Agbenyega, T. and Sallah, L. (2021) Determination of Safe Apnoea Period in Relation to Haemoglobin Concentration at Komfo Anokye Teaching Hospital. Open Access Library Journal, 8: e7930. https://doi.org/10.4236/oalib.1107930

Received: September 6, 2021

Accepted: October 15, 2021

Published: October 18, 2021

Copyright $\odot 2021$ by author(s) and Open Access Library Inc.

This work is licensed under the Creative Commons Attribution International License (CC BY 4.0).

http://creativecommons.org/licenses/by/4.0/

\begin{abstract}
The induced cessation of ventilation or suspension of external breathing is a common occurrence in anaesthetic practice. During the period of induced apnoea, there is no movement of the muscles of inhalation and lung volumes initially remain unchanged. Maintaining haemoglobin saturation during airway management is critical to guarantee the safety of patients. However, there has been little quantitative study of apnoea especially on the rate of change in oxygen saturation in relation to haemoglobin concentration in the apnoeic period of induction of anaesthesia. The study sought to determine the safe apnoea period in relation to haemoglobin concentration. The study showed that patients with low haemoglobin concentration took less time to reach $100 \%$ oxygen saturation, while those with high haemoglobin concentration took more time to reach $100 \%$ oxygen saturation during pre-oxygenation. The study found that the average safe apnoea period for patients in relation to haemoglobin concentrations to desaturation (from 100\% - 92\%) following the administration of suxamethonium was $7.0-9.9 \mathrm{~g} / \mathrm{dl}$ was 3:15.07 minutes, 10.0 $12.9 \mathrm{~g} / \mathrm{dl}$ was $3: 43.05$ minutes and $13.0-16 \mathrm{~g} / \mathrm{dl}$ was 4:23.04 minutes. And the overall safe apnoea time for the patients was 3:27.02 minutes. All the patients who attained $100 \%$ oxygen saturation without inhaling $100 \%$ oxygen were living in mountainous areas. The mean induction period $(6: 52.26 \mathrm{~ms})$ of the patients was higher than the mean safe apnoea period (3:27.02 ms). The study recommends that anaemia should be corrected before induction of anaesthesia and people living at high altitude should be advised to occasionally move down to areas of low altitude to improve tissue oxygenation.
\end{abstract}

\section{Subject Areas}

Anaesthesiology, Pain Management 


\section{Keywords}

Apnoea, Heamoglobin Concentration, Anaesthesia, KATH

\section{Introduction}

The induced cessation of ventilation or suspension of external breathing is a common occurrence in anaesthetic practice. According to Wills and Sirian (2009) [1], safe apnoea period is the duration of time following cessation of breathing or ventilation until critical arterial desaturation occurs $\left(\mathrm{SaO}_{2} 88 \%\right.$ to $\left.90 \%\right)$. Patients undergoing general anaesthesia go through a period of apnoea during laryngoscopy and tracheal intubation, which makes it necessary to ensure safe apnoea period [2].

Health report for 2000-2002 by American Society of Anaesthesiologist Task Force in United Kingdom on Confidential Enquiry into Maternal and Child health associated three out of seven maternal anaesthetic deaths to apnoea as a result of failed endotracheal intubation [3] [4]. A further study in the Netherland for more than two years revealed that $10 \%$ out of 87,000 clients' death associated with anaesthesia was as a result of improper management of apnoea [5]. In addition, most studies in apnoea took place in the settings of advanced and emerging countries with highly sophisticated medical technology. However, there has been little quantitative understanding of apnoea, on the rate of change in oxygen saturation in relation to haemoglobin concentration in the apnoeic period of induction of anaesthesia due to its clinical research limitations, hence the need to study that during suxamethonium apnoea at Komfo Anokye Teaching Hospital.

\section{Materials and Method}

It's an observational research design with independent variables of haemoglobin concentration and administration of induction agent, whereas the dependent variable was oxygen saturation. The population of the study comprised all surgery patients admitted to department of Surgery at Komfo Anokye Teaching Hospital from $1^{\text {st }}$ April to $31^{\text {st }}$ July 2016.

A sample size of Ninety-four was used, Kirkwood and Sterne (2003) [6], this ensured statistical representation of the sample size in relation to the study population. Purposive sampling was used to sample patients from the population, aimed at obtaining clients eligible for the study.

An approved guideline and ethical clearance from Kwame Nkrumah University of Science and Technology Ethics Committee and Committee on Human Resource Publication and Ethics (CHPRE) of Komfo Anokye Teaching Hospital was obtained. Consent was sought from patients and their relatives before the study in which the consent form was read and explained in the local dialect for patients who could not read. 
The patients were grouped into three based on their haemoglobin concentration. Group one for those with haemoglobin concentration 7.0 to $9.9 \mathrm{~g} / \mathrm{dl}$, Group two 10.0 to $12.9 \mathrm{~g} / \mathrm{dl}$ and Group three 13.0 to $16.0 \mathrm{~g} / \mathrm{dl}$. They then had their oxygen saturation with room air checked with Life Box pulse oximeter. Selected patients had their noninvasive blood pressure checked with automated dash 4000 monitor; manual respiratory rate count with breast watch; axillary temperature checked with mercury thermometer; height and weight with body mass index taken with a tape meter and standing scale respectively. Those with haemoglobin concentration checked more than 24 hours before the study, had venous blood sample taken during intravenous set up for haemoglobin concentration and blood group. The clients were then positioned on operating table. The Life Box pulse oximeter was applied to the thumb finger for continuous measure of oxygen saturation before pre-oxygenation and during induction of anaesthesia. The rate of increase in oxygen saturation during pre-oxygenation was recorded against the time as Ti. Each participant underwent routine anaesthesia induction as follows: inhalation of $100 \%$ oxygen for three minutes, administration of an anaesthetic agent of choice by anaesthetist, followed by suxamethonium $1 \mathrm{mg} / \mathrm{kg}$. The rate of increase in oxygen saturation during pre-oxygenation was recorded against the time as Ti. The face mask was removed for laryngoscopy and intubation after fasciculation. The time between the administrations of induction agent until the end of endotracheal intubation during the apnoeic period was recorded against the time for each participant for each group as Table 1.

In cases where patient desaturated to $92 \%$ before a successful intubation, then patient was ventilated to raise the oxygen saturation to $100 \%$ before the next attempt of intubation and the values for the repeated time was recorded as $T_{1}$ per table a with respect to the changes in oxygen saturation. The induction agent used, duration of induction, diagnosis, type of surgery and premedication used were recorded.

Table 1. Times for recording apnoeic period for the participants.

\begin{tabular}{ccc}
\hline Oxygen saturation \% & Time period in milliseconds $\mathrm{T}$ & $\begin{array}{c}\text { Time period in } \\
\text { milliseconds } \mathrm{T}_{1} \text { (second attempt) }\end{array}$ \\
\hline 100 & $\mathrm{~T} 100$ & $\mathrm{~T}_{1} 100$ \\
99 & $\mathrm{~T} 99$ & $\mathrm{~T}_{1} 99$ \\
98 & $\mathrm{~T} 98$ & $\mathrm{~T}_{1} 98$ \\
97 & $\mathrm{~T} 97$ & $\mathrm{~T}_{1} 97$ \\
96 & $\mathrm{~T} 96$ & $\mathrm{~T}_{1} 96$ \\
95 & $\mathrm{~T} 95$ & $\mathrm{~T}_{1} 95$ \\
94 & $\mathrm{~T} 94$ & $\mathrm{~T}_{1} 94$ \\
93 & $\mathrm{~T} 93$ & $\mathrm{~T}_{1} 93$ \\
92 & $\mathrm{~T} 92$ & $\mathrm{~T}_{1} 92$ \\
\hline
\end{tabular}


The data were processed using Microsoft Excel 2010 Professional Edition.

Descriptive statistics such as means, standard deviation as well as inferential statistics such as correlation and one-way analysis of variance were used to analyse data collected. An error margin of 0.05 was used for all inferential analyses.

\section{Results}

A little over half (52.1\%) of the patients were females, while $47.9 \%$ were males.

Patients presented for surgery based on the classification of American Society of Anaesthesiology (ASA), with 55.3\% being emergency and $44.7 \%$ being elective.

Table 2 represents perioperative haemoglobin level groupings with $66 \%$ classified as anamia and $34 \%$ being normal.

7.0 - $9.9 \mathrm{~g} / \mathrm{dl}$ - Moderate anaemia

10.0 - $12.9 \mathrm{~g} / \mathrm{dl}$ - Mild anaemia

13.0 - $16.0 \mathrm{~g} / \mathrm{dl}$ - Normal blood level

Figure 1 presents result of preoperative fitness of patients presented for surgery based on the classification of American Society of Anaesthesiology (ASA), with 55.3\% (ASAIE + ASAIIE) being emergency and $44.7 \%$ being elective.

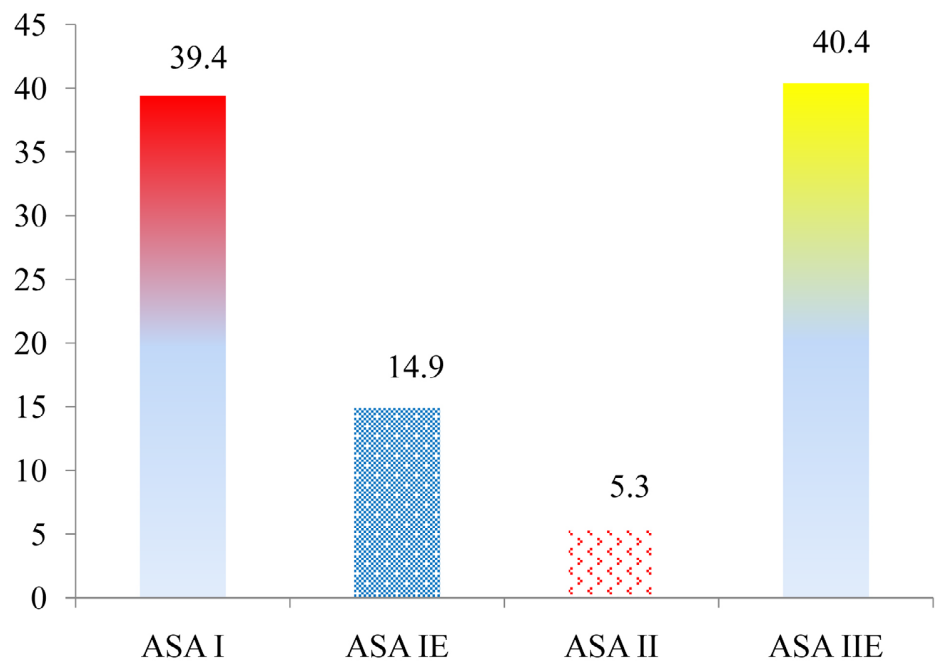

Figure 1. Percentages of preoperative physical status of the patients presented for surgery. Source: Field data (2016).

Table 2. Preoperative haemoglobin concentration levels of sampled patients.

\begin{tabular}{ccc}
\hline Hb level $(\mathrm{g} / \mathrm{dl})$ & Frequency & Percentage \\
\hline $7.0-9.9$ & 29 & 30.9 \\
$10.0-12.9$ & 33 & 35.1 \\
$13.0-16.0$ & 32 & 34.0 \\
Total & 94 & 100.0 \\
\hline
\end{tabular}

Source: Field data (2016). 
ASA I-Normal healthy patient: $39.4 \%$

ASA IE-Normal healthy patient who required emergency surgery: $14.9 \%$

ASA II-Patient with mild systemic disease; no functional limitation: 5.3\%

ASA IIE-Patient with mild systemic disease who required emergency surgery: $40.4 \%$

Table 3 shows BMI data on sample size with 68\% (normal), 27.7\% (overweight) and $4.3 \%$ (obese).

Below $25 \mathrm{~kg} / \mathrm{m}^{2}$ - Normal BMI

$25-29.9 \mathrm{~kg} / \mathrm{m}^{2}$-Overweight

30 and plus $\mathrm{kg} / \mathrm{m}^{2}$-Obese

Table 4 represents mean oxygen saturation of $97 \%$ in relation to different haemoglobin concentration groupings of patient's breathing room air during anaesthetic assessment. And those with haemoglobin concentration of $7.0-9.9$ none attained $100 \%$ saturation.

Table 5 shows no statistical significance since significant value of 0.974 was more than acceptable margin of error 0.05 . Imply that there were similar oxygen saturations with room air across the three haemoglobin concentrations.

Table 3. Frequency and percentage of body mass index of patients presented for surgery.

\begin{tabular}{ccc}
\hline BMI $\left(\mathbf{k g}\right.$ per $\left.\mathbf{~ m}^{2}\right)$ & Frequency & Percentage \\
\hline Below 25 & 64 & 68.0 \\
$25-29.9$ & 26 & 27.7 \\
30 and plus & 4 & 4.3 \\
Total & 94 & 100.0 \\
\hline
\end{tabular}

Source: Field data (2016).

Table 4. Oxygen saturation of patients' breathing room air with difference in haemoglobin concentration levels during anaesthetic assessment.

\begin{tabular}{ccccc}
\hline Hb levels $(\mathrm{g} / \mathrm{dl})$ & $\mathrm{N}$ & Mean $\mathrm{SpO}_{2}$ & Min & Max \\
\hline $7.0-9.9$ & 29 & 97.24 & 94.0 & 99.0 \\
$10.0-12.9$ & 33 & 97.21 & 93.0 & 100.0 \\
$13.0-16.0$ & 32 & 97.16 & 94.0 & 100.0 \\
Total & 94 & 97.20 & 93.0 & 100.0 \\
\hline
\end{tabular}

Source: Field data (2016).

Table 5. One-way analysis of variance on $\mathrm{SpO}_{2}$ of patient's breathing room air across haemoglobin concentration levels to show statistical significance.

\begin{tabular}{cccc}
\hline Groups & Sum of squares & F & Sig. \\
\hline Between groups & 0.115 & 0.026 & 0.974 \\
Within groups & 203.044 & & \\
Total & 203.160 & &
\end{tabular}

Source: Field survey (2016). Sig. value for Levene's test $=0.341$. 
Sig. value $=p$-value (probability value $)$-it is the actual error associated with the test

$\mathrm{df}=$ degree of freedom (number of sub-categories minus one)

F-statistic $=$ Anova value

Data comparing oxygen saturation before induction among the three haemoglobin concentration levels of the sampled patients with mean $\mathrm{SpO}_{2}$ of $97 \%$ across the three different haemoglobin level groups and those with haemoglobin of 7.0 - 9.9 none attained 100\% Oxygen saturation with room air (Table 6).

From the Table 7, a Sig value for the Levene's test of 0.297 shows that the analysis did not violate the assumption of homogeneity of variance. This was because the Sig. value for Levene's test of 0.297 was greater than the accepted margin of error of 0.05 .

Sig. value $=p$-value (probability value $)-$ it is the actual error associated with the test

$\mathrm{df}=$ degree of freedom (number of sub-categories minus one)

F-statistic $=$ Anova value

The results (Table 8) showing that patients with low haemoglobin concentration took less time to reach maximum oxygen saturation, while those with high haemoglobin concentration took more time to reach oxygen saturation during pre-oxygenation. The results further show a positive relationship between haemoglobin concentration levels and time taken by patients to reach oxygen saturation during pre-oxygenation.

As shown in Table 9, there is statistical significant association among the different haemoglobin concentration levels in relation to the rate of increase in oxygen saturation during pre-oxygenation.

Table 6. Oxygen saturation of patients' breathing room air with difference in haemoglobin concentration levels before induction of anaesthesia.

\begin{tabular}{ccccc}
\hline Hb levels $(\mathrm{g} / \mathrm{dl})$ & $\mathrm{N}$ & Mean of $\mathrm{SpO}_{2}$ & Min & Max \\
\hline $7.0-9.9$ & 29 & 97.55 & 94.0 & 99.0 \\
$10.0-12.9$ & 33 & 97.24 & 93.0 & 100.0 \\
$13.0-16.0$ & 32 & 97.09 & 92.0 & 100.0 \\
Total & $\mathbf{9 4}$ & $\mathbf{9 7 . 2 9}$ & $\mathbf{9 2 . 0}$ & 100.0 \\
\hline
\end{tabular}

Source: Field data (2016).

Table 7. One-way analysis of variance on $\mathrm{SpO}_{2}$ before induction across haemoglobin concentration levels to assess statistical significance.

\begin{tabular}{cccc}
\hline Groups & Sum of squares & F & Sig. \\
\hline Between groups & 3.293 & 0.539 & 0.585 \\
Within groups & 277.952 & & \\
Total & 281.245 & & \\
\hline
\end{tabular}

Source: Field survey (2016). Sig. value for Levene's test $=0.297$. 
Table 8. Rate of increase in oxygen saturation (in milliseconds) in relation to haemoglobin concentration during pre-oxygenation at induction of anaesthesia.

\begin{tabular}{ccccc}
\hline Hb levels $(\mathrm{g} / \mathrm{dl})$ & N & Mean & Min & Max \\
\hline $7.0-9.9$ & 29 & $0: 53.46$ & $0: 19.09$ & $4: 49.06$ \\
$10.0-12.9$ & 33 & $1: 18.01$ & $0: 24.04$ & $3: 00.00$ \\
$13.0-16.0$ & 32 & $2: 11.32$ & $0: 00.00$ & $3: 34.05$ \\
Total & 94 & $1: 28.45$ & $0: 00.00$ & $4: 49.06$ \\
\hline
\end{tabular}

Source: Field data (2016).

Table 9. One-way analysis of variance on rate of increase in oxygen saturation in relation to haemoglobin concentration during pre-oxygenation to assess statistical significance.

\begin{tabular}{cccc}
\hline Groups & Sum of squares & F & Sig. \\
\hline Between groups & $352,325,739.3$ & 14.783 & 0.001 \\
Within groups & $1,084,427,878$ & & \\
Total & $1,436,753,617$ & & \\
\hline
\end{tabular}

Source: Field survey (2016). Sig. value of $0.001($ F-statistic $=14.783)$.

Sig. value for Levene's test $=0.392$ (Levene statistic $=0.947)$

Eta squared $=0.25$

Sig. value $=p$-value (probability value) - it is the actual error associated with the test

$\mathrm{df}=$ degree of freedom (number of sub-categories minus one)

F-statistic $=$ Anova value

Eta squared $=$ statistical tool for measuring the size of an effect

Multiple comparism of mean rate of increase in $\mathrm{SpO}_{2}$ during preoxygenation (Table 10), showing the mean score for patients with haemoglobin concentration of $13.0-16.0 \mathrm{~g} / \mathrm{dl}$ (mean $=2: 11.32$; stdv. $=0: 57.06)$ was significantly different from that of patients with haemoglobin concentration of $7.0-9.9 \mathrm{~g} / \mathrm{dl}$ (mean $=0: 53.46 ;$ stdv. $=1: 03.24)$, and patients with haemoglobin concentration of 10.0 - $12.9($ mean $=1: 18.01 ;$ stdv. $=0: 52.18)$ in relation to the rate of increase in oxygen saturation during pre-oxygenation.

Data on mean rate of oxygen desaturation from $100 \%-92 \%$ following suxamethonium administration of sampled patients showing increased mean rate as haemoglobin concentration increases (safe apnoea period in relation to haemoglobin concentration) as follows: 7.0 - 9.9, $10.0-12.9$ and $13.0-16.0$ to 3:15.07, 3:43.05 and 4:23.04 minutes respectively. Plus overall mean rate of desaturation from $100 \%$ to $92 \%$ being 3:27.02 minutes (Table 11 ).

The results of a one-way analysis of variance with post hoc test showing statistical significance of the observed differences in the rate of oxygen desaturation in relation to haemoglobin concentration following the administration of suxamethonium as significant value of 0.001 is within an acceptable error margin of 0.05 (Table 12). 
Table 10. Multiple comparison for rate of increase in $\mathrm{SpO}_{2}$ during pre-oxygenation.

\begin{tabular}{|c|c|c|c|c|c|c|}
\hline \multicolumn{7}{|c|}{ Multiple Comparisons } \\
\hline \multicolumn{7}{|c|}{ Dependent Variable: $\mathrm{Ti}=$ rate of increase in $\mathrm{SpO}_{2}$ during preoxygenation } \\
\hline \multicolumn{7}{|c|}{ Tukey HSD } \\
\hline \multirow{2}{*}{$\begin{array}{l}\text { (I) haemoglobin } \\
\text { concentration } \\
\text { categories }\end{array}$} & \multirow{2}{*}{$\begin{array}{l}\text { (J) haemoglobin } \\
\text { concentration } \\
\text { categories }\end{array}$} & \multirow{2}{*}{$\begin{array}{c}\text { Mean } \\
\text { Difference } \\
(\mathrm{I}-\mathrm{J})\end{array}$} & \multirow{2}{*}{$\begin{array}{l}\text { Std. } \\
\text { Error }\end{array}$} & \multirow{2}{*}{ Sig. } & \multicolumn{2}{|c|}{$\begin{array}{l}\text { 95\% Confidence } \\
\text { Interval }\end{array}$} \\
\hline & & & & & $\begin{array}{l}\text { Lower } \\
\text { Bound }\end{array}$ & $\begin{array}{l}\text { Upper } \\
\text { Bound }\end{array}$ \\
\hline \multirow{2}{*}{$7.0-9.9 \mathrm{~g} / \mathrm{dl}$} & $10-12.9 \mathrm{~g} / \mathrm{dl}$ & $-0: 24: 15$ & $0: 14: 38$ & 0.227 & $-0: 59: 09$ & $0: 10: 37$ \\
\hline & $13-16 \mathrm{~g} / \mathrm{dl}$ & $-1: 17: 46^{*}$ & $0: 14: 45$ & 0.000 & $-1: 52: 55$ & $-0: 42: 37$ \\
\hline \multirow{2}{*}{$10.0-12.9 \mathrm{~g} / \mathrm{dl}$} & $7-9.9 \mathrm{~g} / \mathrm{dl}$ & $0: 24: 15$ & $0: 14: 38$ & 0.227 & $-0: 10: 37$ & 0:59:09 \\
\hline & $13-16 \mathrm{~g} / \mathrm{dl}$ & $-0: 53: 30^{\star}$ & $0: 14: 16$ & 0.001 & $-1: 27: 31$ & $-0: 19: 29$ \\
\hline \multirow{2}{*}{$13.0-16.0 \mathrm{~g} / \mathrm{dl}$} & $7-9.9 \mathrm{~g} / \mathrm{dl}$ & $1: 17: 46^{\star}$ & $0: 14: 45$ & 0.000 & $0: 42: 37$ & 1:52:55 \\
\hline & $10-12.9 \mathrm{~g} / \mathrm{dl}$ & $0: 53: 30^{*}$ & $0: 14: 16$ & 0.001 & $0: 19: 29$ & $1: 27: 31$ \\
\hline
\end{tabular}

*The mean difference is significant at the 0.05 level. Source: Field survey (2016).

Table 11. Mean rates of change (minutes) in oxygen desaturation in relation to haemoglobin concentration following suxamethonium administration from $100 \%$ to $92 \%$.

\begin{tabular}{cccccc}
\hline Time of desaturation & $\mathbf{N}$ & $\mathbf{7 - 9 . 9} \mathbf{~} / \mathrm{dl}$ & $\mathbf{1 0 - 1 2 . 9} \mathbf{g} / \mathrm{dl}$ & $\mathbf{1 3}-\mathbf{1 6} \mathbf{~} / \mathrm{dl}$ & Total \\
\hline No change in $\mathrm{SpO}_{2}$ & 94 & $2: 33.35$ & $3: 31.16$ & $3: 39.26$ & $3: 15.44$ \\
Time for $\mathrm{SpO}_{2}$ at $99 \%$ & 48 & $2: 56.57$ & $3: 43.56$ & $3: 22.37$ & $3: 16.15$ \\
Time for $\mathrm{SpO}_{2}$ at $98 \%$ & 35 & $3: 05.24$ & $3: 50.43$ & $3: 30.42$ & $3: 16.46$ \\
Time for $\mathrm{SpO}_{2}$ at $97 \%$ & 27 & $3: 12.31$ & $3: 26.26$ & $3: 49.06$ & $3: 19.14$ \\
Time for $\mathrm{SpO}_{2}$ at $96 \%$ & 27 & $3: 20.25$ & $3: 34.44$ & $4: 02 . .02$ & $3: 25.06$ \\
Time for $\mathrm{SpO}_{2}$ at $95 \%$ & 26 & $3: 26.26$ & $3: 39.21$ & $4: 06.03$ & $3: 30.58$ \\
Time for $\mathrm{SpO}_{2}$ at $94 \%$ & 26 & $3: 33.18$ & $3: 49.03$ & $4: 07.33$ & $3: 37.45$ \\
Time for $\mathrm{SpO}_{2}$ at $93 \%$ & 24 & $3: 34.45$ & $3: 52.23$ & $4: 39.06$ & $3: 39.38$ \\
Time for $\mathrm{SpO}_{2}$ at $92 \%$ & 20 & $3: 39.35$ & $4: 05.07$ & $4: 41.03$ & $3: 45.12$ \\
$\quad \mathrm{Total}^{2}$ & $\mathbf{9 4}$ & $\mathbf{3 : 1 5 . 0 7}$ & $3: 43.05$ & $4: 23.04$ & $3: 27.02$ \\
\hline
\end{tabular}

Source: Field data (2016).

Table 12. One-way analysis of variance on rate of desaturation of oxygen in relation to haemoglobin concentration following suxamethonium administration.

\begin{tabular}{cccc}
\hline Groups & Sum of squares & F & Sig. \\
\hline Between groups & $278,731,535.410$ & 18.541 & 0.001 \\
Within groups & $684,026,504.644$ & & \\
Total & $962,758,040.053$ & & \\
\hline
\end{tabular}

Source: Field survey (2016). 
Sig. value for Levene's test $=0.264($ Levene statistic $=1.350)$

Eta squared $=0.29$

Sig. value $=p$-value (probability value $)-$ it is the actual error associated with the test

$\mathrm{df}=$ degree of freedom (number of sub-categories minus one)

F-statistic $=$ Anova value

Eta squared $=$ statistical tool for measuring the size of an effect

The post-hoc analysis conducted on the areas of comparison between haemoglobin concentrations to where differences in the means of oxygen desaturation following suxamethonium administration showing statistically significant between haemoglobin concentration of 7.0 - 9.9 and other two groups and no statistical significant difference between haemoglobin concentration of $10.0-12.9$ and 13.0 - 16.0 (Table 13).

Data (Table 14) showing normal vital signs of sampled patients who attained $100 \%$ oxygen saturation without inhaling $100 \%$ oxygen being similar to those who did not attained $100 \%$ oxygen saturation.

Table 15 represents an average induction of 6:52.26 minutes.

Data (Table 16) showing no statistical significant relation between induction period and safe apnoea period.

Sig. value $=p$-value $($ probability value $)-i$ is the actual error associated with the test

Pearson correlation $=$ Measures the strength and direction of relationship $\mathrm{N}$ = sample size

Table 13. Multiple comparison for rate of oxygen desaturation (100\% - 92\%) following suxamethonium administration.

\begin{tabular}{|c|c|c|c|c|c|c|}
\hline \multicolumn{7}{|c|}{ Multiple Comparisons } \\
\hline \multicolumn{7}{|c|}{$\begin{array}{l}\text { Dependent Variable: } \\
\text { average change in } \mathrm{SpO}_{2}(100 \%-92 \%) \\
\text { following suxamethonium administration }\end{array}$} \\
\hline \multicolumn{7}{|c|}{ Tukey HSD } \\
\hline \multirow{2}{*}{$\begin{array}{l}\text { (I) haemoglobin } \\
\text { concentration } \\
\text { categories }\end{array}$} & \multirow{2}{*}{$\begin{array}{l}\text { (J) haemoglobin } \\
\text { concentration } \\
\text { categories }\end{array}$} & \multirow{2}{*}{$\begin{array}{l}\text { Mean } \\
\text { Difference } \\
\quad(\mathrm{I}-\mathrm{J})\end{array}$} & \multirow{2}{*}{$\begin{array}{l}\text { Std. } \\
\text { Error }\end{array}$} & \multirow{2}{*}{ Sig. } & \multicolumn{2}{|c|}{$\begin{array}{l}\text { 95\% Confidence } \\
\text { Interval }\end{array}$} \\
\hline & & & & & $\begin{array}{l}\text { Lower } \\
\text { Bound }\end{array}$ & $\begin{array}{l}\text { Upper } \\
\text { Bound }\end{array}$ \\
\hline \multirow{2}{*}{$7-9.9 \mathrm{~g} / \mathrm{dl}$} & $10-12.9 \mathrm{~g} / \mathrm{dl}$ & $-0: 57: 40^{*}$ & $0: 11: 37$ & 0.000 & $-1: 25: 23$ & $-0: 29: 58$ \\
\hline & $13-16 \mathrm{~g} / \mathrm{dl}$ & $-1: 05: 50^{\star}$ & $0: 11: 42$ & 0.000 & $-1: 33: 45$ & $-0: 37: 55$ \\
\hline \multirow{2}{*}{$10-12.9 \mathrm{~g} / \mathrm{dl}$} & $7-9.9 \mathrm{~g} / \mathrm{dl}$ & $0: 57: 40^{*}$ & $0: 11: 37$ & 0.000 & 0:29:58 & $1: 25: 23$ \\
\hline & $13-16 \mathrm{~g} / \mathrm{dl}$ & $-0: 08: 09$ & $0: 11: 20$ & 0.752 & $-0: 35: 10$ & $0: 18: 50$ \\
\hline \multirow{2}{*}{$13-16 \mathrm{~g} / \mathrm{dl}$} & $7-9.9 \mathrm{~g} / \mathrm{dl}$ & $1: 05: 50^{*}$ & $0: 11: 42$ & 0.000 & $0: 37: 55$ & $1: 33: 45$ \\
\hline & $10-12.9 \mathrm{~g} / \mathrm{dl}$ & 0:08:09 & $0: 11: 20$ & 0.752 & $-0: 18: 50$ & $0: 35: 10$ \\
\hline
\end{tabular}

*The mean difference is significant at the 0.05 level. Source: Field survey (2016). 
Table 14. Mean vital signs of patients attaining 100\% oxygen saturation without inhaling $100 \%$ oxygen.

\begin{tabular}{|c|c|c|c|c|}
\hline \multirow{2}{*}{ Vital signs } & \multirow{2}{*}{ Mean } & \multirow{2}{*}{ Stdv. } & \multicolumn{2}{|c|}{ Range } \\
\hline & & & Min & Max \\
\hline Body mass index & & & $20.43 \mathrm{~kg} / \mathrm{m}^{2}$ & $25.21 \mathrm{~kg} / \mathrm{m}^{2}$ \\
\hline Arterial blood pressure (before ind.) & $134 / 75 \mathrm{mmHg}$ & & $125 / 70 \mathrm{mmHg}$ & $148 / 75 \mathrm{mmHg}$ \\
\hline Arterial blood pressure (during ind.) & $134 / 75 \mathrm{mmHg}$ & & $120 / 63 \mathrm{mmHg}$ & $148 / 91 \mathrm{mmHg}$ \\
\hline Pulse rate before induction & $94.4 \mathrm{bpm}$ & 18.47 & $67 \mathrm{bpm}$ & $112 \mathrm{bpm}$ \\
\hline Pulse rate during induction & $105.8 \mathrm{bpm}$ & 105.8 & $92 \mathrm{bpm}$ & $133 \mathrm{bpm}$ \\
\hline Respiratory rate & $14 \mathrm{cpm}$ & & $14 \mathrm{cpm}$ & $14 \mathrm{cpm}$ \\
\hline Tidal volume & $362.8 \mathrm{ml}$ & 64.64 & $280 \mathrm{ml}$ & $431 \mathrm{ml}$ \\
\hline Temperature & $36.7\left({ }^{\circ} \mathrm{C}\right)$ & 0.29 & $36.4\left({ }^{\circ} \mathrm{C}\right)$ & $37\left({ }^{\circ} \mathrm{C}\right)$ \\
\hline
\end{tabular}

Source: Field survey (2016).

Table 15. Minimum, maximum and mean Induction period of anaesthesia induction.

\begin{tabular}{ccc}
\hline \multirow{2}{*}{ Mean } & \multicolumn{2}{c}{ Range } \\
\cline { 2 - 3 } & Min & Max \\
\hline $6: 52.26 \mathrm{~ms}$ & $5: 27.06 \mathrm{~ms}$ & \multirow{2}{*}{$14: 49.02 \mathrm{~ms}$} \\
\hline
\end{tabular}

Source: Field survey (2016).

Table 16. Pearson correlation between duration of induction and safe apnoea period of patients to show the strength of the relation.

\begin{tabular}{ccc}
\hline & Duration of induction & Safe apnoea period \\
\hline Pearson Correlation & 1 & 0.050 \\
Sig. (2-tailed) & & 0.635 \\
$\mathrm{~N}$ & 94 & 94 \\
\hline
\end{tabular}

Source: Field survey (2016).

\section{Discussion}

The results show that preoperative anaemia was prevalent in the majority (66\%) of the patients. This result is in agreement with the finding of Baron et al., (2014) [7] that preoperative anaemia had a high prevalence in both adult men and women (31.1\% and $26.5 \%$, respectively).

From the study, the majority (55.3\%) of patients were operated under emergency circumstances. This is likely to affect extensive preoperative assessment for effective airway management as described by Lane et al., (2005) [8].

The study found that patients with low haemoglobin concentration took less time to achieve $100 \%$ oxygen saturation, while those with high haemoglobin concentration took more time to reach $100 \%$ oxygen saturation during pre-oxygenation. This disagrees with the assertion of Davis et al. (2008) [9] that patients with high haemoglobin concentration reach oxygen saturation faster than those with low 
haemoglobin concentration. However, Baillard et al., (2006) [10] posited that high haemoglobin count could occur when the body requires an increased oxygen-carrying capacity, especially for patients who smoke and those living at higher altitude.

The average time taken for patients to de-saturate from $100 \%$ oxygen to $92 \%$ in relation to haemoglobin concentrations with suxamethonium apnoea were 7.0 $9.9 \mathrm{~g} / \mathrm{dl}$ was 3:15.07 minutes, 10.0 - $12.9 \mathrm{~g} / \mathrm{dl}$ was 3:43.05 minutes and 13.0 - 16 $\mathrm{g} / \mathrm{dl}$ was 4:23.04 minutes, with overall the mean safe apnoea period of the sampled patients being 3:27.02 minutes. These were lower than the six to eight minutes suggested by Nielsen et al., (2008) [11] as the normal time for desaturation. This could be attributed to the fact that anaesthesia reduces the functional residual capacity of patients, as well as increase oxygen consumption from suxamethonium fasciculation, which causes faster rate of desaturation following the administration of suxamethonium according to Weingart (2012) [2]. This also disagrees with Oddo et al., (2006) [12] that the importance of haemoglobin is not in the storage of oxygen but in its effective transport from the lungs to the tissues.

None of the sampled patients with haemoglobin concentration level $7.0-9.9$ attained $100 \%$ oxygen saturation compared to those with $10.0-12.9$ and 13.0 16 when breathing room air during anaesthetic assessment and before induction of anaesthesia which according to Davis et al., (2008) [9] indicates anaemic hypoxia.

All the patients who attained $100 \%$ oxygen saturation without inhaling $100 \%$ oxygen had the majority $(80 \%)$ of such patients with haemoglobin concentration of $13-16 \mathrm{~g} / \mathrm{dl}$ and $20 \%$ had haemoglobin concentration of $10-12.9 \mathrm{~g} / \mathrm{dl}$ and were living in mountainous areas and within the active working age group (30 45 years) with respiratory rate of $14 \mathrm{cpm}$.

This was in agreement with the assertion of Palkovits et al., (2014) [13] that people living at high altitudes have low arterial partial pressure of oxygen, low partial pressure of carbon dioxide resulting slight increase in arterial $\mathrm{pH}$ and for that matter increases their haemoglobin affinity to oxygen which makes them attain $100 \%$ saturation without releasing oxygen. However, this result disagrees with the assertion of McCahon and Hardman (2007) [14] that people of high altitude lack oxygen because of the negative relationship between oxygen saturation in air and altitude.

From the study, the mean induction period of the patients was $6: 52.26 \mathrm{~ms}$ which was higher than the mean safe apnoea period (3:27.02). Per the argument of Davis et al., (2008) [9], the implication is that the patients were generally at risk. This is because such patients have to be re-oxygenated in the process to guarantee their safety in the physiological processes before surgery.

\section{Conclusions}

The study found a positive relationship between haemoglobin concentration levels and time taken by patients to reach $100 \%$ oxygen saturation during pre- 
oxygenation.

The time for oxygen desaturation among the patients was directly or positively related to the level of haemoglobin concentration.

All the patients who attained $100 \%$ oxygen saturation without inhaling $100 \%$ oxygen were living in mountainous areas.

The study concludes that haemoglobin concentration plays a critical role in the induction and apnoea period.

\section{Limitation of the Study}

Since the study was conducted in human, the critical desaturation point of $88 \%$ $90 \%$ was set at $92 \%$.

Another limitation of the study was difficulty of the researcher to obtain the background information about some of the patients because of pain.

\section{Recommendations}

The following recommendations were made to ensure safe apnoea period in patients in relation to haemoglobin concentration.

1) Anaemia must be corrected before induction of general anaesthesia in order to ensure safe apnoea period.

2) Awake anaemic hypoxia patients compensate better than during induction of anaesthesia and for that matter induction period for anaemic patient, when necessary must be done with accurate speed.

3) The study also recommend all intubators to use the apnoeic oxygenation technique for all critically ill patient during laryngoscopy and intubation

4) The study recommends that the Ghana Health Service should deploy an online database application system to store the medical and surgical records of people in the country.

5) Educational programmes to educate the public on nutrition to enable people consume balance diet that would help maintain adequate haemoglobin concentration in their bodies.

\section{Suggestion for Further Study}

The study suggests that further studies should be conducted into causes or reasons why patients who lived in mountainous areas attained $100 \%$ oxygen without inhaling $100 \%$ oxygen.

In such a study, the selection of patients should be based on altitude of place of stay. Regression and factor analyses could be used to determine the factors which account for the attainment of $100 \%$ oxygen without inhaling $100 \%$ oxygen.

\section{Acknowledgements}

Our sincerest gratitude and highest praise to the Almighty God, the lifter of men, for his uncommon grace and favor throughout this study. 


\section{Conflicts of Interest}

The authors declare no conflicts of interest.

\section{References}

[1] Wills, J. and Sirian, R. (2009) Physiology of Apnoea and the Benefits of Preoxygenation. Continuing Education in Anaesthesia Critical Care \& Pain, 9, 105-108. https://doi.org/10.1093/bjaceaccp/mkp018

[2] Weingart, S.D. and Levitan, R.M. (2012) Preoxygenation and Prevention of Desaturation during Emergency Airway Management. Annals of Emergency Medicine, 59, 165-175. https://doi.org/10.1016/j.annemergmed.2011.10.002

[3] American Society of Anesthesiologists (2003) Practice Guidelines for Management of the Difficult Airway. An Update Report by the American Society of Anesthesiologists Task Force on Management of the Difficult Airway. Anesthesiology, 98, 1269-1277. https://doi.org/10.1097/00000542-200305000-00032

[4] Peterson, G.N., Domino, K.B., Caplan, R.A., Posner, K.L., Lee, L.A. and Cheney, F.W. (2005) Management of the Difficult Airway. A Closed Claims Analysis. Anesthesiology, 103, 33-39. https://doi.org/10.1097/00000542-200507000-00009

[5] Arbous, M.S., Grobbee, D.E., Van Kleef, J.W., De Lange, J.J., Spoormans, H.H.A.J.M., Touw, P., Werner, F.M. and Meursing, A.E.E. (2001) Mortality Associated with Anaesthesia: A Qualitative Analysis to Identify Risk Factors. Anaesthesia, 56, 1141-1153.

[6] Kirkwood, B.R. and Sterne, J.A.C. (2003) Essential Medical Statistics. 2nd Edition. Blackwell Science, Malden, Massachusetts, 501p.

[7] Baron, D.M., Hochrieser, H., Posch, M., Metnitz, B., Rhodes, A., Moreno, R.P., Pearse, R.M., Metnitz, P. and Myles, P.S. (2014) Peroperative Anaemia Is Associated with Poor Outcome in Non-Cardiac Surgery Patients. British Journal of Anaesthesia, 113, 416-423.

[8] Lane, S., Saunders, D. and Schofield, A. (2005) A Prospective, Randomised Controlled Trial Comparing the Efficacy of Preoxygenation in the 20 Degrees Head-Up vs. Supine Position. Anaesthesia, 60, 1064-1067.

https://doi.org/10.1111/j.1365-2044.2005.04374.x

[9] Davis, D.P., Hwang, J.Q. and Dunford, J.V. (2008) Rate of Decline in Oxygen Saturation at Various Pulse Oximetry Values with Prehospital Rapid Sequence Intubation. Prehospital Emergency Care, 12, 46-51. https://doi.org/10.1080/10903120701710470

[10] Baillard, C., Fosse, J.P. and Sebbane, M. (2006) Noninvasive Ventilation Improves Preoxygenation before Intubation of Hypoxic Patients. American Journal of Respiratory and Critical Care Medicine, 174, 171-177. https://doi.org/10.1164/rccm.200509-1507OC

[11] Nielsen, N.D., Kjaergaard, B. and Koefoed-Nielsen, J. (2008) Apneic Oxygenation Combined with Extracorporeal Arteriovenous Carbon Dioxide Removal Provides Sufficient Gas Exchange in Experimental Lung Injury. ASAIO Journal, 54, 401-405. https://doi.org/10.1097/MAT.0b013e31817e2b5f

[12] Oddo, M., Feihl, F. and Schaller, M.D. (2006) Management of Mechanical Ventilation in Acute Severe Asthma: Practical Aspects. Intensive Care Medicine, 32, 501-510. https://doi.org/10.1007/s00134-005-0045-x

[13] Palkovits, S., Lasta, M., Told, R., Schmidl, D., Boltz, A. and Napora, K.J. (2014) Retinal Oxygen Metabolism during Normoxia and Hyperoxia in Healthy Subjects. Investigative Ophthalmology \& Visual Science, 55, 4707-4713. 
https://doi.org/10.1167/iovs.14-14593

[14] McCahon, R.A. and Hardman, J.G. (2007) Fighting for Breath: Apnea vs. the Anaesthetized. Anaesthesia, 62, 105-108. https://doi.org/10.1111/j.1365-2044.2007.04932.x 